\title{
Costs of Biological and Cultural Resource Protection to the U.S. Natural Gas Industry
}

\author{
Mitch Kunce ${ }^{1}$
}

\begin{abstract}
Using a unique land transaction from the 1860s in the Western U.S., this paper examines whether the presence of biological and cultural resources on private and federal land increase drilling costs to the U.S. natural gas industry. Our results suggest that the presence of these resources can increase costs, but the effect depends on the land type and which resources are being protected. The presence of threatened and endangered species increase drilling costs significantly on both federal and private lands; whereas the existence of migratory wildlife like elk and pronghorn does not. Cultural resources have a differentiated impact-they raise drilling costs significantly on federal lands, but not on private lands.
\end{abstract}

JEL classification numbers: C23, Q58.

Keywords: Endangered Species, U.S. Natural Gas, Cultural Resources, Drilling Costs.

${ }^{1}$ Douglas Mitchell Econometric Consulting, Laramie, Wyoming USA.

Article Info: Received: December 7, 2020. Revised: December 24, 2020.

Published online: December 28, 2020. 


\section{Introduction}

To what extent does current environmental and land use policy in the United States protect biological and cultural resources from oil and gas drilling? Are these resources protected from drilling more vigorously on federal property than on private property? Little information is available on these long-standing questions except for impressionistic evidence from operators, Congressional testimony by industry representatives (Hackett 2001 and Committee on Resources 2001), and a small number of engineering cost studies (Harder, et al. 1995 and Penn 1986). Yet, they are directly related to policy issues including how the regulatory structure in the oil and gas industry actually works, what steps the government might take to improve regulatory efficiency, and whether surface resources nearby to drilling sites are over or under-protected. These issues are of particular current importance in light of the recent surge in domestic natural gas drilling activity in response to increasing demand.

More broadly, little is known about how endangered species protection affects costs in any industry. Brown, et al (1998), for example, review how the protection of endangered species can increase costs for the few industries actually studied. The cost estimates range from substantial to nearly zero: Some $\$ 30-40$ billion in welfare losses to protect 2400 pairs of Northern Spotted Owls in the Northwest (Montgomery et al. 1994), about \$300 million in lost annual power revenues due to salmon protection by the Bonneville Power Administration (also see Huppert 1999), and the minimal losses associated with protecting fishes in two rivers in the southwest (Watts et al. 2001). Few additional studies have emerged in the past two decades to provide much guidance.

Given the paucity of evidence on actual protection costs, this paper estimates empirically how protection of biological and cultural resources on federal and private property affects oil and natural gas drilling costs within a unique land area of southwest Wyoming over the period 1987-2004. The land area is a roughly 12,300 square miles from Rawlins, Wyoming to the Utah state line along the historic Transcontinental Union Pacific rail road line. A distinguishing characteristic of this area is an alternating pattern of land ownership, established in the 1860s via the Pacific Railway Acts 1862, 1864, in which each federally owned (square mile) section is surrounded by four privately owned sections and each privately owned section is surrounded by four federally owned sections. Remarkably, this land ownership pattern has not been greatly disturbed since establishment by the Railway Acts. The locations of cultural artifacts, wildlife habitat and seasonal migratory routes together with the ownership pattern of private and federal property serve as experimental controls to identify the incremental cost of protection and to test hypotheses about possible asymmetric protection of various types of resources on the two types of property. Results suggest that presence of big game wildlife, such as elk, mule deer and pronghorn, does not increase drilling cost either on federal or private property. In contrast, the presence of threatened and endangered species, including mountain plover and sage grouse, significantly increases drilling costs on 
both types of land and increases costs disproportionately on federal property. Drilling costs also are significantly higher on federal property that shelters objects of cultural significance, but not on private property. Results presented below indicate that biological and cultural resources account for about $76 \%$ of the measured federal land drilling cost premium. These findings, however, do not support the previously cited evidence and Congressional testimony that concluded:

I. all biological and cultural resources are more vigilantly protected on federal property than on private property and

II. the entire drilling cost premium on federal land is due to more stringent protection of these resources.

This article is organized into three additional sections to describe the data, econometric results, and implications and conclusions of the analysis.

\section{Data}

This section describes the data on drilling costs, oil and gas fields, and biological and cultural resources in the drilling land area. The American Petroleum Institute (API), through the Joint Association Survey on Drilling Costs, tabulates drilling costs obtained from operators on each completed well drilled in the United States, including dry holes (see, for example, the 2005 Joint Association Survey on Drilling Costs, Section 3 for details). Types of costs reported for each well drilled include variable cost items such as labor, materials, supplies, machinery and tools, water, transportation, fuel, and power. Information also is obtained about costs of direct overhead such as for permitting and site preparation, road building, drilling pit construction, erecting and dismantling derricks/drilling rigs, hauling and disposal of waste materials, and site restoration. These data, available for each completed well in the U.S., measure drilling cost, depth (in feet), surface land ownership (private, federal, state, tribal, or land for which ownership is contested), well type (oil, gas, coalbed methane, dry) and well location (township, range, section, as well as longitude and latitude to five decimal place accuracy). In total, data are available on 2,658 properly located wells drilled between the years 1987-2004. A disadvantage of these data is that components of drilling costs are not individually itemized. Thus, costs of compliance with particular environmental regulations cannot be directly identified.

Information about drilling costs was matched to data on the location of geologic fields containing oil and gas. The Wyoming Oil and Gas Conservation Commission has identified 87 oil and gas fields in the described land area. Each of these fields is large enough to encompass both private and federal sections of land. Drilling occurred in 57 fields over the period 1987-2004 and of the 2,658 wells drilled during these years, 1,855 (70.0\%) were drilled in 8 fields. As Figure 1 shows, these fields are concentrated between the towns of Rock Springs/Green River and Wamsutter; an area where pronghorn and mule deer range land is concentrated. 


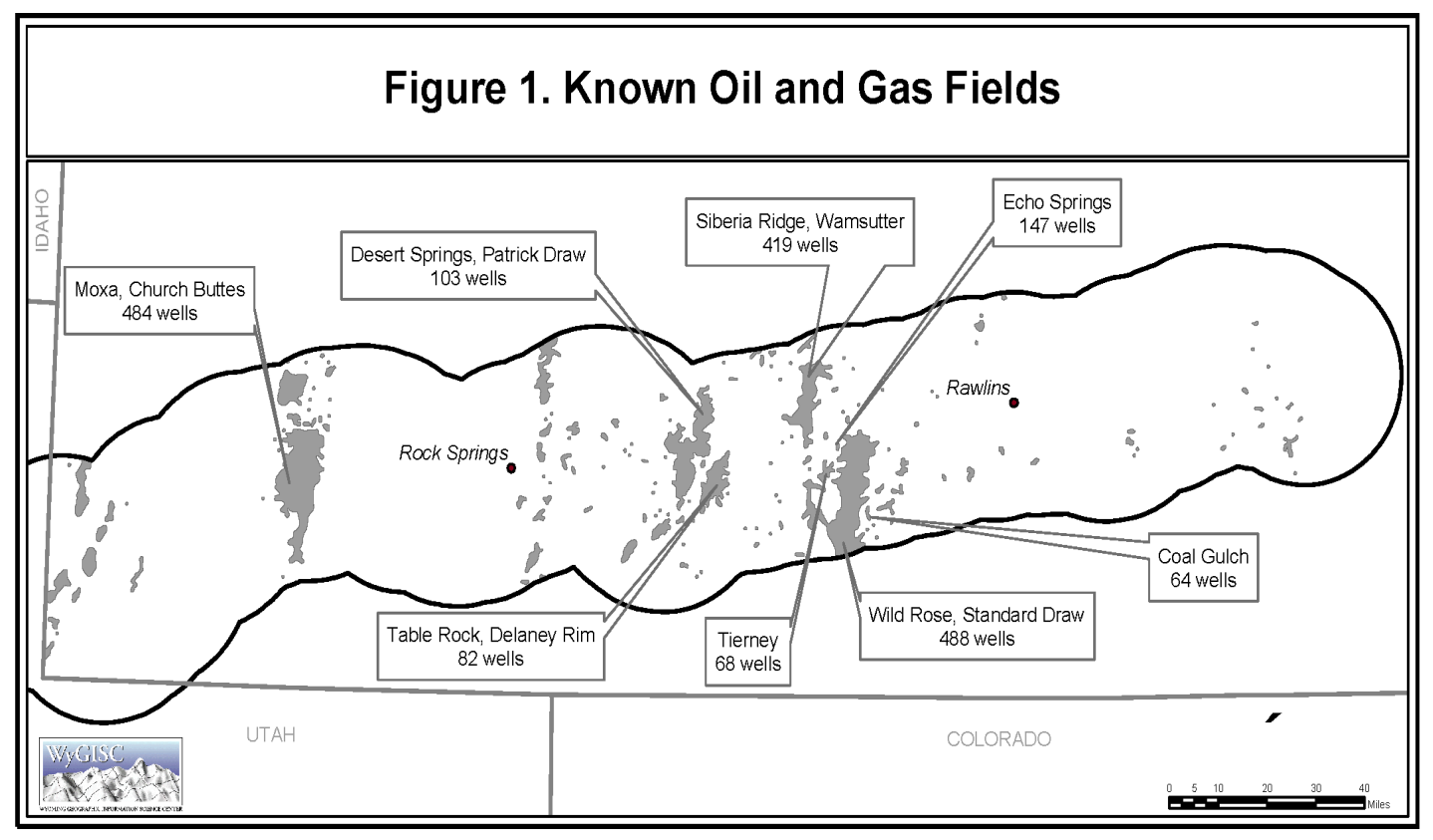

Figure 1: Known Oil and Gas Fields

The data set used in the econometric analysis consists of 2357 observations on completed wells drilled in 55 fields on both private and federal property over the period 1987-2004: 98 wells drilled on land owned by the State of Wyoming, 109 coalbed methane wells and 94 wells drilled outside the 87 known oil or gas fields were excluded. Wells drilled on State land were excluded because they are relatively few in number and our main purpose is to contrast drilling costs on federal and private property. Coalbed methane wells were excluded because of major drilling differences from traditional oil and gas wells. Generally, drilling a coalbed seam in southwest Wyoming for methane involves drilling a shallow (1,500-4,000 feet) water well with a truck-mounted drill rig. This experience differs significantly from traditional oil and gas derrick drilling. Wells drilled outside of known fields were excluded because it is useful to confine attention to the alternating ownership sections where oil and gas drilling is more likely to take place and where geologic differences between fields can be controlled. Natural gas wells and oil wells comprise $89.8 \%$ and $5.3 \%$ of the 2357 observation sample and dry holes make up the remaining $4.9 \%$. The relatively small percentage of dry holes suggests that development wells outnumber exploratory wells and may reflect recent improvements in reservoir identification technology such as three-dimensional seismic imaging.

The data indicate that a greater percentage of drilling occurs on private land and that drilling on federal property is more costly than on private property. Forty-two percent of sample wells were drilled on federal property and 58\% of wells were drilled on private property. The average real cost of drilling a well on both types of 
land combined was $\$ 1.18$ million and average real drilling costs on federal property exceeded average real drilling costs on private property by $\$ 231,000$. The null hypothesis that an equal percentage of wells are drilled on both types of property is rejected at the 5\% level and the average cost difference between federal and private property differs significantly from zero at the $5 \%$ level under a difference between means test, assuming independent samples. The null hypothesis that the percentage of dry wells is the same on federal and private property is not rejected at the 5\% level. Thus, drilling success rates on federal and private property are about the same. The findings of significantly higher drilling cost on federal property and equal success rates on both types of property raises the question of why any wells would be drilled on federal land. A possible answer is that drilling costs vary by geologic field and land ownership. Cost heterogeneity among fields may lead operators to drill on federal sections in a low-cost field rather than on private sections in a highcost field. Two sources of evidence suggest that cost heterogeneity among fields may be present. First, most drilling has occurred in a small number of fields and some fields have received little attention to date. Second, estimates described more fully in the next section consistently reject the null hypothesis of no cost heterogeneity among the 55 fields where drilling has occurred at significance levels below $1 \%$ (see Table 2 below and accompanying discussion).

To complete the data set, well locations also were matched to locations of cultural and biological resources. The number of cultural resource sites in each section is available from the Cultural Resources Management Statistics maintained by the Wyoming Cultural Records Office. This Office does not make public exact locations and characteristics of cultural resources, but it does release enough information to place each site within a land section. A site is defined as an area where human activity occurred and artifacts remain. Artifacts must be at least fifty years old to be included in the inventory. Sites range in size from small scatters of artifacts to historic forts and range in age from the Paleo-Indian period (13,000 years ago) to the early 1950s. In land sections where oil and gas drilling occurred over the period 1987-2004, the number of cultural sites ranges from 0 to 48 with a mean of 3.9. Depending on the type of cultural resources, and their proximity to the drilling area, operators might be required to conduct a surface site survey, specific site testing, or an archaeological excavation. These activities will increase drilling costs as reported in the previously cited Joint Association Survey.

Year-round and crucial winter rangeland is identified for the four big game species living in southwest Wyoming (elk, pronghorn, mule deer, and moose) using the Wyoming Game and Fish Department's Big Game Seasonal Ranges database. This database reflects the location of big game rangeland during the 2000s. Yearround and crucial winter rangeland is defined as land a population of animals makes general use of on a year-round basis but during the winter months (December-April) this habitat becomes crucial to a population's ability to maintain itself at a certain level (theoretically at or above a population objective). Migration routes also were obtained for each of the four types of animals from the Wyoming Open Spaces Initiative, Wyoming Game and Fish Department. Of the total 7,878,502 acres in the 
Railway Act land, range land and migration routes comprise 1,835,732 and 35,902 acres for pronghorn, 379,454 and 7,271 acres for elk, 79,456 and 6,622 acres for moose, and 937,635 and 32,042 acres for mule deer. As shown in Figure 2, habitat and migration routes sometimes overlap for two or more species. Habitat acreage for all four animals combined totals roughly $27 \%$ of the land area shown.

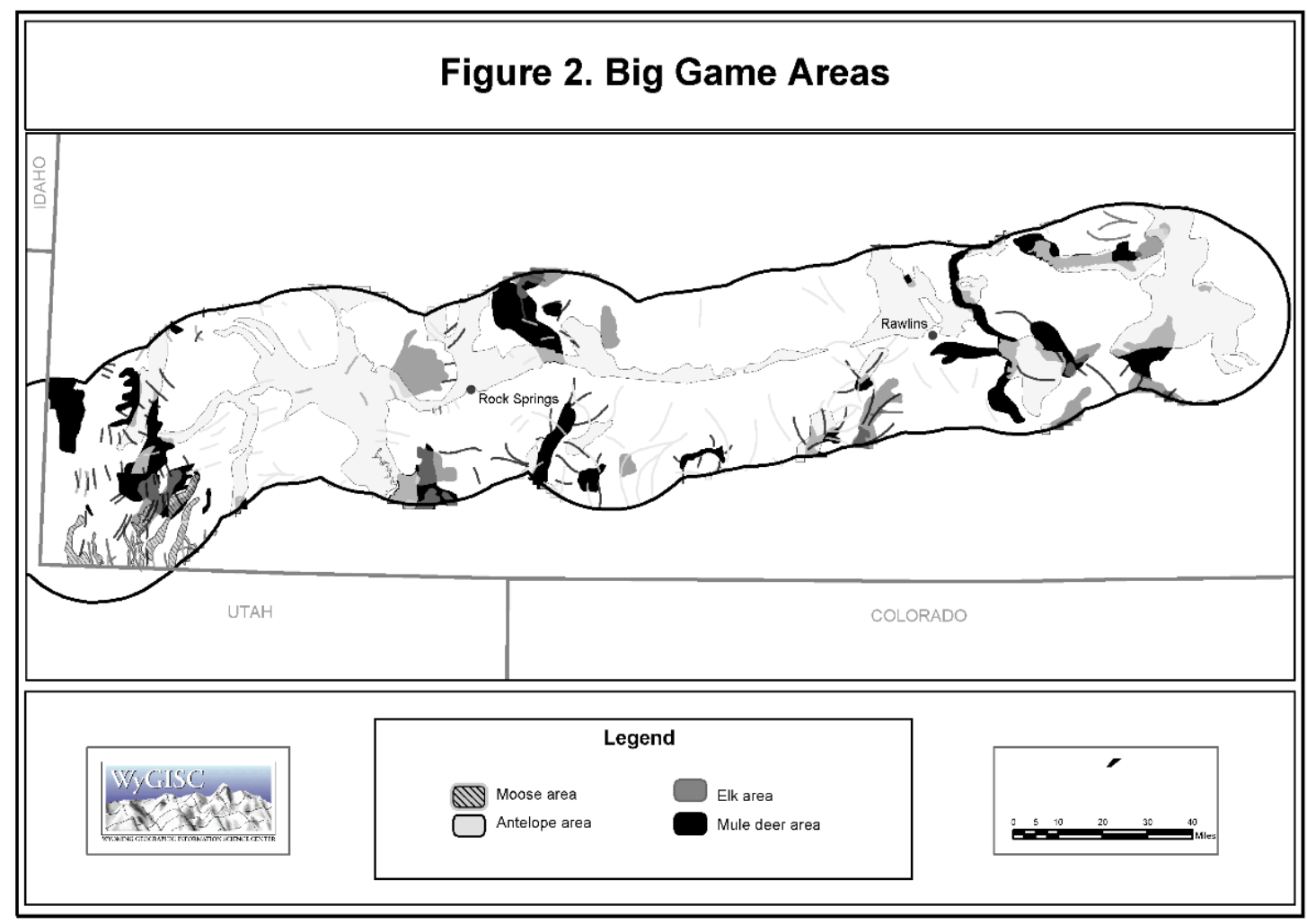

Figure 2: Big Game Areas

Of the 2,658 oil and gas wells drilled over the period 1987-2004, 424 were drilled within pronghorn range/migration habitat, 70 wells were drilled within mule deer habitat, and 19 were drilled within elk habitat. No drilling on moose range/migration land was observed, but moose habitat does not intersect with areas where oil and gas reserves are known to exist (see Figures 1 and 2). A total of 24 wells were drilled where pronghorn and mule deer habitat overlap, which nets total wells drilled in big game habitat from 513 to 489.

Data on the location of threatened and endangered species habitat is taken from the Wyoming Natural Diversity Database and the Bureau of Land Management's Sensitive Species List. Data describe information on the biology and location of listed or candidate threatened and endangered native plant and animal species as defined by the U.S. Forest Service (Brown et al. 1998). Species include the blackfooted ferret (Mustela nigripes; endangered), the Preble's meadow jumping mouse (Zapus hudsonius preblei; threatened), the mountain plover (Charadrius montanus; 
candidate), and the sage grouse (Centrocercus urophasianus; potential candidate). No threatened and endangered plant species have been identified in the land area. Total acreage of threatened and endangered species habitat is comprised of blackfooted ferret area of 33,426 acres, jumping mice acreage of 11,142, mountain plover acreage of 457,367, and sage grouse habitat of 65,474 acres.

Because these four areas slightly overlap, as shown in Figure 3, the net threatened and endangered species habitat totals 551,247 acres, about $7 \%$ of the land area. Seventy-nine wells were drilled in mountain plover habitat and 59 wells were drilled in sage grouse habitat. Nine of 138 wells were drilled in the area where sage grouse, pronghorn, and mule deer habitats intersect. No drilling occurred within blackfooted ferret or jumping mouse habitat. These areas are relatively small and are not located within known oil and gas fields (see Figures 1 and 3). Combining wells drilled within big game range/migration land with threatened and endangered habitat yields a total of $618(489+138-9)$ wells within these key sensitive areas. The combined total acreage, netting out overlapping areas, encompasses $2,651,707$ acres (roughly 34\%) of the subject land area.

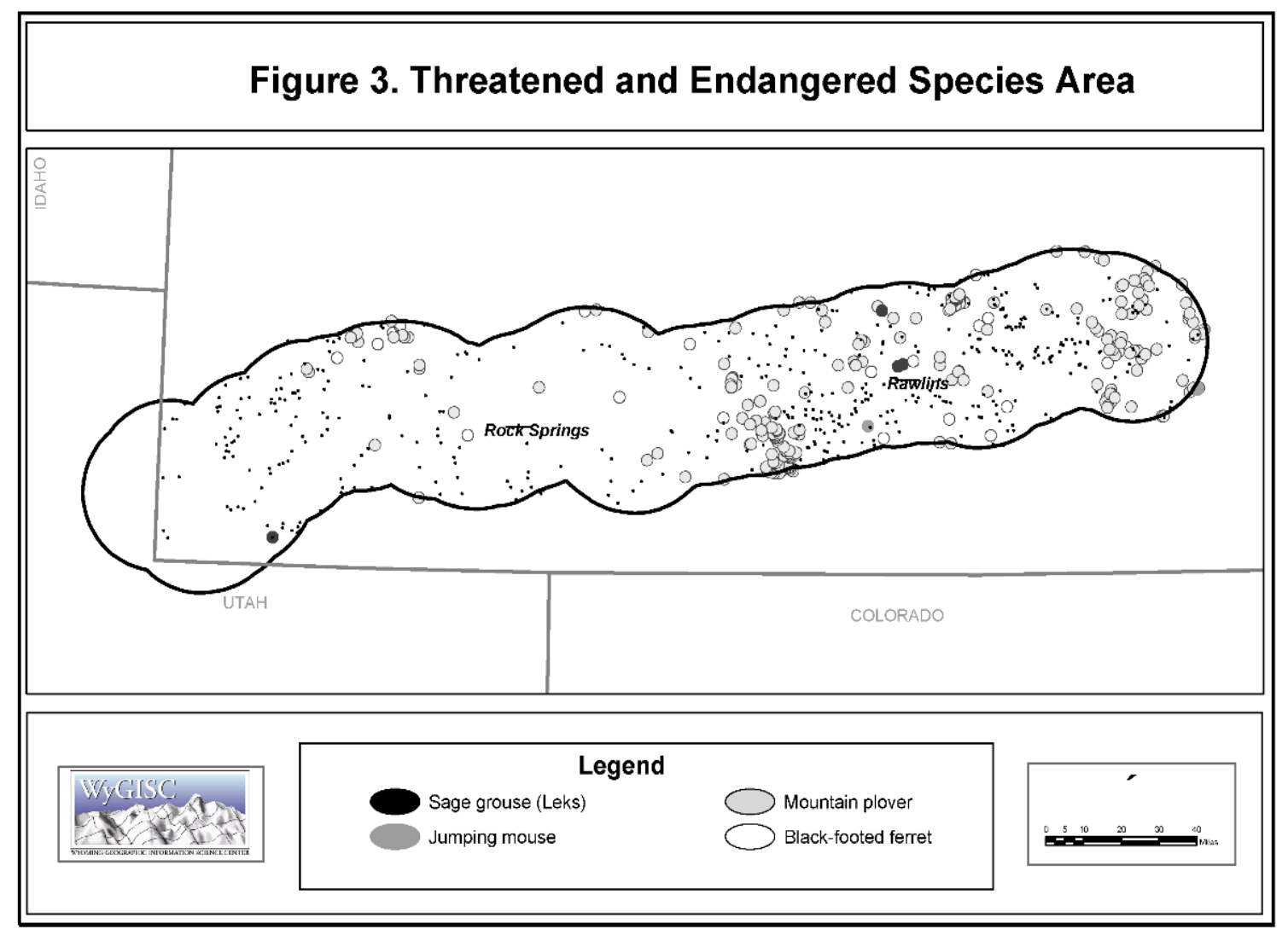

Figure 3: Threatened and Endangered Species Area 


\section{Econometric Estimates}

Equation (1) is used to estimate determinants of drilling costs.

Real drilling cost $=f$ (land ownership, well depth, big game habitat, threatened or endangered species habitat, cultural sites, well type, field, year) + error.

In equation (1), observation subscripts have been suppressed to economize on notation. The dependent variable denotes the real cost of drilling a well in thousands of year 2000 dollars, land ownership is a dummy variable indicating whether a section is under federal management or in private hands, well depth denotes dummy variables indicating whether the well was relatively shallow (less than 9,750 feet), midrange (between 9,750 and 11,450 feet), or relatively deep (greater than 11,450 feet), big game habitat is a dummy variable indicating the presence of pronghorn, mule deer, and/or elk habitat or migratory routes, threatened or endangered species is a dummy variable indicating the presence of mountain plover or sage grouse habitat, cultural sites is the number of cultural sites present in the section where each well was drilled, well type denotes dummy variables indicating whether the well was an oil, gas, or dry well, field denotes fixed effects to capture unobserved heterogeneity in drilling cost among the 55 oil and gas fields in which wells were drilled, year denotes fixed effects for each of the 18 years in the sample period to account for factors such as productivity changes, and error reflects the net effect on drilling cost of all factors not otherwise controlled. Table 1 provides descriptions of means of all variables for the complete sample as well as for the federal and private land sub-samples. 
Table 1: Variable Descriptions and Sample Means

\begin{tabular}{|l|c|c|c|}
\hline Variable & $\begin{array}{c}\text { Total } \\
\text { Sample } \\
\text { Means }\end{array}$ & $\begin{array}{c}\text { Federal } \\
\text { Property } \\
\text { Means }\end{array}$ & $\begin{array}{c}\text { Private } \\
\text { Property } \\
\text { Means }\end{array}$ \\
\hline Drilling Cost in thousands of year 2000 dollars & 1,185 & 1,319 & 1,088 \\
\hline$=1$ if well is located on federal property, 0 otherwise & 0.420 & -- & -- \\
\hline$=1$ if well depth is less than 9,750 feet, 0 otherwise & 0.338 & 0.348 & 0.336 \\
\hline $\begin{array}{l}=1 \text { if well depth is between 9,750 and 11,450 feet, 0 } \\
\text { otherwise }\end{array}$ & 0.330 & 0.302 & 0.351 \\
\hline $\begin{array}{l}=1 \text { if well depth is greater than 11,450 feet, 0 } \\
\text { otherwise }\end{array}$ & 0.332 & 0.350 & 0.313 \\
\hline $\begin{array}{l}=1 \text { if well is in elk, mule deer or pronghorn } \\
\text { habitat/migratory routes, 0 otherwise }\end{array}$ & 0.182 & 0.177 & 0.186 \\
\hline $\begin{array}{l}\text { Interaction of shallow depth and elk, mule deer, } \\
\text { pronghorn habitat }\end{array}$ & -- & 0.047 & 0.037 \\
\hline $\begin{array}{l}\text { Interaction of mid-range depth and elk, mule deer, } \\
\text { pronghorn habitat }\end{array}$ & -- & 0.017 & 0.033 \\
\hline $\begin{array}{l}\text { Interaction of deep depth and elk, mule deer, } \\
\text { pronghorn habitat }\end{array}$ & -- & 0.113 & 0.116 \\
\hline $\begin{array}{l}=1 \text { if well is in mountain plover or sage grouse } \\
\text { habitat, 0 otherwise }\end{array}$ & 0.056 & 0.062 & 0.052 \\
\hline $\begin{array}{l}\text { Interaction of shallow depth and mountain plover/sage } \\
\text { grouse habitat }\end{array}$ & -- & 0.045 & 0.039 \\
\hline $\begin{array}{l}\text { Interaction of mid-range depth and mountain } \\
\text { plover/sage grouse habitat }\end{array}$ & -- & 0.014 & 0.011 \\
\hline $\begin{array}{l}\text { Interaction of deep depth and mountain plover/sage } \\
\text { grouse habitat }\end{array}$ & -- & 0.003 & 0.002 \\
\hline $\begin{array}{l}\text { Number of cultural sites in a section where a well is } \\
\text { drilled }\end{array}$ & 4.19 & 5.67 & 3.13 \\
\hline $\begin{array}{l}\text { Interaction of shallow depth and number of cultural } \\
\text { sites }\end{array}$ & -- & 2.24 & 1.41 \\
\hline $\begin{array}{l}\text { Interaction of mid-range depth and number of cultural } \\
\text { sites }\end{array}$ & -- & 0.63 & 0.54 \\
\hline Interaction of deep depth and number of cultural sites & -- & 2.80 & 1.18 \\
\hline$=1$ if a gas well, 0 otherwise & 0.898 & 0.914 & 0.886 \\
\hline$=1$ if an oil well, 0 otherwise & 0.053 & 0.046 & 0.058 \\
\hline$=1$ if a dry hole, 0 otherwise & 2357 & 9940 & 0.056 \\
\hline Number of observations & & & 1366 \\
\hline
\end{tabular}

Two further aspects of equation (1) warrant discussion before presenting the estimates shown in Table 2. First, while land ownership in this area was assigned in the 1860s without regard to the underlying geology or to surface resources, operators have chosen drilling sites by considering expected costs and payoffs at 
alternative locations. This implies the land sections are not randomly selected when drilling, so sample selection bias is a potential concern. Sample selection bias is investigated using a variable addition test proposed by Wooldridge (1995) and further discussed by Baltagi (2005, pp. 222-224). The test involves estimating Tobit models for each year to explain the number of wells drilled in each of 998 land sections where drilling was observed. Focusing on the 2357 wells drilled over all years, 5 wells drilled in a single section in one year occurred 6 times, 4 wells drilled occurred 22 times, 3 wells drilled occurred 72 times, 2 wells drilled occurred 293 times and 1 well drilled in a single section in one year occurred 1437 times. Each of the 18 models included the same covariates as in equation (1) except for depth and well type, which are unknown prior to completing a well, and year. Residuals from these regressions then were combined into a single variable that was included as a covariate in equation (1). Coefficients of this variable were not significantly different from zero at the 5\% level in all versions of equation (1) estimated (see Appendix Table A1) and whether this variable was included had little effect on coefficients of the other covariates. In consequence, the null hypothesis of no sample selection bias was not rejected and the residual variable was excluded from the specifications reported in Table 2.

Second, because the data analyzed are explicitly spatial, each of the regressions in Table 2 is tested for presence of spatial dependence using the general diagnostic cross-section dependence (CD) test for unbalanced panels proposed by Pesaran (2004). This test involves computing an asymptotically normally distributed statistic based on the average of all land section pair-wise correlation coefficients of the residuals. Pesaran's CD test has advantages over the generalized Lagrange multiplier (LM) approach of Breusch and Pagan (1980) because it is correctly centered at mean zero for panel specifications possessing a large number of crosssections with relatively fewer time periods. The Breusch-Pagan LM test suffers from substantial size distortions when panels have a large number of cross-sections. Because wells are not drilled in each section each year, the pair-wise correlations of residuals are computed using the common period data for each possible land section pairing. For example, assume wells were drilled in section 1 in 1988, 1990, 1991, 1995, 1997, and 2000 and in section 2 in 1990, 1995, 1997, and 2000. This pairwise correlation of residuals would be computed for the common (intersecting) periods 1990, 1995, 1997, and 2000 (Pesaran (2004, p. 17)). In addition, a more localized test was constructed by limiting the land section pairing to within field only (Pesaran 2004, p. 11). The CD test statistics, reported for each specification in Table 2, fails to reject the null hypothesis of no spatial dependence for all equations reported.

Three versions of equation (1) are estimated to establish the role of biological and cultural resources in determining drilling costs: (I) a baseline model that excludes these resource variables, (II) a biological and cultural resource model that includes them, and (III) the biological and cultural resource model separately estimated using federal and private land sub-samples. 
Table 2: Determinants of Real Drilling Cost (in thousands of 2000 dollars) ${ }^{a}$

\begin{tabular}{|c|c|c|c|c|}
\hline Variable & $\begin{array}{l}\text { Baseline } \\
\text { Model }\end{array}$ & $\begin{array}{l}\text { Historical/ } \\
\text { Biological }\end{array}$ & $\begin{array}{r}\text { Federal } \\
\text { Property }\end{array}$ & $\begin{array}{l}\text { Private } \\
\text { Property }\end{array}$ \\
\hline Constant & $\begin{array}{l}473.1^{*} \\
(36.2)\end{array}$ & $\begin{array}{l}350.3^{*} \\
(40.1)\end{array}$ & $\begin{array}{l}328.8^{*} \\
(73.5)\end{array}$ & $\begin{array}{l}689.1^{*} \\
(39.0)\end{array}$ \\
\hline $\begin{array}{l}=1 \text { if well is located on federal property, } 0 \\
\text { otherwise }\end{array}$ & $\begin{array}{l}162.6^{*} \\
(28.6)\end{array}$ & $\begin{array}{l}139.6^{*} \\
(28.7)\end{array}$ & -- & -- \\
\hline $\begin{array}{l}=1 \text { if well depth is between } 9,750 \text { and } 11,450 \text { feet, } \\
0 \text { otherwise }\end{array}$ & $\begin{array}{l}489.1^{*} \\
(44.3)\end{array}$ & $\begin{array}{l}578.1^{*} \\
(45.6)\end{array}$ & $\begin{array}{l}707.5^{*} \\
(93.7) \\
\end{array}$ & $\begin{array}{l}288.8^{*} \\
(49.6)\end{array}$ \\
\hline $\begin{array}{l}=1 \text { if well depth is greater than } 11,450 \text { feet, } 0 \\
\text { otherwise }\end{array}$ & $\begin{array}{c}1,560.7^{*} \\
(60.2)\end{array}$ & $\begin{array}{c}1,625.3^{*} \\
(60.3)\end{array}$ & $\begin{array}{c}1,923.9^{*} \\
(110.0)\end{array}$ & $\begin{array}{l}885.8^{*} \\
(62.7)\end{array}$ \\
\hline $\begin{array}{l}=1 \text { if well is in elk, mule deer or pronghorn } \\
\text { habitat/migratory routes, } 0 \text { otherwise }\end{array}$ & -- & $\begin{array}{l}72.0 \\
(43.0)\end{array}$ & -- & -- \\
\hline $\begin{array}{l}\text { Interaction of shallow depth and elk, mule deer, } \\
\text { pronghorn habitat }\end{array}$ & -- & -- & $\begin{array}{c}191.9 \\
(171.3)\end{array}$ & $\begin{array}{l}-29.0 \\
(85.9)\end{array}$ \\
\hline $\begin{array}{l}\text { Interaction of mid-range depth and elk, mule deer, } \\
\text { pronghorn habitat }\end{array}$ & -- & -- & $\begin{array}{c}166.2 \\
(191.4)\end{array}$ & $\begin{array}{c}69.4 \\
(73.6)\end{array}$ \\
\hline $\begin{array}{l}\text { Interaction of deep depth and elk, mule deer, } \\
\text { pronghorn habitat }\end{array}$ & -- & -- & $\begin{array}{l}-68.2 \\
(91.1)\end{array}$ & $\begin{array}{c}78.4 \\
(49.2)\end{array}$ \\
\hline $\begin{array}{l}=1 \text { if well is in mountain plover or sage grouse } \\
\text { habitat, } 0 \text { otherwise }\end{array}$ & -- & $\begin{array}{l}284.5^{*} \\
(62.9)\end{array}$ & -- & -- \\
\hline $\begin{array}{l}\text { Interaction of shallow depth and mountain } \\
\text { plover/sage grouse habitat }\end{array}$ & -- & -- & $\begin{array}{l}238.7^{*} \\
(122.6)\end{array}$ & $\begin{array}{c}44.1 \\
(67.9)\end{array}$ \\
\hline $\begin{array}{l}\text { Interaction of mid-range depth and mountain } \\
\text { plover/sage grouse habitat }\end{array}$ & -- & -- & $\begin{array}{c}326.2 \\
(409.9)\end{array}$ & $\begin{array}{l}141.9^{*} \\
(12.2)\end{array}$ \\
\hline $\begin{array}{l}\text { Interaction of deep depth and mountain } \\
\text { plover/sage grouse habitat }\end{array}$ & -- & -- & $\begin{array}{l}559.9^{*} \\
(140.3)\end{array}$ & $\begin{array}{l}450.8^{*} \\
(117.9)\end{array}$ \\
\hline $\begin{array}{l}\text { Number of cultural sites in a section where a well } \\
\text { is drilled }\end{array}$ & -- & $\begin{array}{r}12.0^{*} \\
(2.3)\end{array}$ & -- & -- \\
\hline $\begin{array}{l}\text { Interaction of shallow depth and number of } \\
\text { cultural sites }\end{array}$ & -- & -- & $\begin{array}{l}10.9^{*} \\
(5.7)\end{array}$ & $\begin{array}{c}1.4 \\
(3.1)\end{array}$ \\
\hline $\begin{array}{l}\text { Interaction of mid-range depth and number of } \\
\text { cultural sites }\end{array}$ & -- & -- & $\begin{array}{l}-6.6 \\
(9.8)\end{array}$ & $\begin{array}{l}-0.1 \\
(5.7)\end{array}$ \\
\hline $\begin{array}{l}\text { Interaction of deep depth and number of cultural } \\
\text { sites }\end{array}$ & -- & -- & $\begin{array}{l}32.1^{*} \\
(5.5)\end{array}$ & $\begin{array}{l}1.5 \\
(4.2)\end{array}$ \\
\hline$=1$ if an oil well, 0 otherwise & $\begin{aligned}-505.7^{*} \\
(83.1) \\
\end{aligned}$ & $\begin{aligned}-483.9^{*} \\
(82.3)\end{aligned}$ & $\begin{array}{l}-775.6^{*} \\
(141.6)\end{array}$ & $\begin{array}{l}-54.7 \\
(78.4) \\
\end{array}$ \\
\hline$=1$ if a dry hole, 0 otherwise & $\begin{array}{r}-209.4^{*} \\
(71.8) \\
\end{array}$ & $\begin{array}{r}-191.5^{*} \\
(71.1) \\
\end{array}$ & $\begin{array}{l}-365.8^{*} \\
(141.9) \\
\end{array}$ & $\begin{array}{l}-20.1 \\
(62.4) \\
\end{array}$ \\
\hline Number of observations & 2357 & 2357 & 991 & 1366 \\
\hline Fixed effects vs Random effects, Hausman (df) & $80.8(5)$ & $146.2(8)$ & $71.2(13)$ & $86.2(14)$ \\
\hline Field effects, F-test (df) & $\begin{array}{c}16.5 \\
(54,2297) \\
\end{array}$ & $\begin{array}{c}17.0 \\
(54,2294) \\
\end{array}$ & $\begin{array}{c}12.0 \\
(44,933) \\
\end{array}$ & $\begin{array}{c}13.4 \\
(50,1302) \\
\end{array}$ \\
\hline $\begin{array}{l}\text { Time effects after removing Field effects, F-test } \\
\text { (df) }\end{array}$ & $\begin{array}{c}15.0 \\
(17,2280)\end{array}$ & $\begin{array}{c}15.0 \\
(17,2277)\end{array}$ & $\begin{array}{c}7.8 \\
(17,916)\end{array}$ & $\begin{array}{c}14.7 \\
(17,1285)\end{array}$ \\
\hline $\begin{array}{l}\text { General Cross-section dependence test } \\
\text { (number of Checkerboard sections }(\mathrm{N}) \text { ) }\end{array}$ & $\begin{array}{c}0.44 \\
(998)\end{array}$ & $\begin{array}{c}0.43 \\
(998)\end{array}$ & $\begin{array}{c}0.22 \\
(421)\end{array}$ & $\begin{array}{c}0.14 \\
(577)\end{array}$ \\
\hline $\mathrm{R}^{2}$ & 0.49 & 0.51 & 0.59 & 0.66 \\
\hline
\end{tabular}

${ }^{\mathrm{a}}$ standard errors in parenthesis, ${ }^{*}$ significant at the $5 \%$ level 


\subsection{Baseline model}

Column (2) of Table 2 presents estimates of the baseline model obtained by OLS. All coefficient estimates are significantly different from zero at the 5\% level or lower and $\mathrm{R}^{2}=0.49$. F-tests indicate that field effects and year effects are jointly and significantly different from zero at $5 \%$ as well. Coefficient estimates indicate that after controlling for well depth, well type, field effects and year effects, the estimated average drilling cost premium on federal property is about $\$ 163$ thousand. This estimate is smaller by $\$ 68$ thousand than the previously discussed corresponding estimate obtained from a comparison of raw means (see Table 1). Estimates also show that drilling cost increases at an increasing rate with well depth. Whereas it costs an average of $\$ 578$ thousand more to drill to a depth between 9,750 feet and 11,450 feet than to a depth between less than 9750 feet, it costs $\$ 1.625$ million to drill wells to a depth exceeding 11,450 feet than wells less than 9,00 feet. Additionally, natural gas wells are more expensive than both oil wells and dry holes. Natural gas wells are more expensive than oil wells because, among other factors, they must be engineered to handle greater underground pressures. Dry holes are less expensive to complete because operators may have an incentive to give up when evidence from drilling suggests that going further will not yield a positive result.

\subsection{Biological and cultural resource model}

Column (3) of Table 2 shows the outcome of adding variables measuring the presence of biological and cultural resources to the baseline model. Results again indicate that both field effects and year effects are jointly significantly different from zero at the $5 \%$ level. The $\mathrm{R}^{2}=0.51$. Compared to the baseline model, coefficient estimates of the well depth and well type variables are little changed from the baseline model.

Now consider the key findings from this regression. Drilling a well in a land section with cultural sites and with threatened/endangered species habitat significantly increases drilling costs. For each additional cultural site in a section, real drilling cost increases by $\$ 12$ thousand. This means a well drilled in a section with the mean number of cultural sites (4.19) costs about $\$ 50$ thousand more than a similar well drilled in a section with no such sites. In addition, locating a well in threatened/endangered species habitat significantly increases drilling costs.

About $5.6 \%$ of all wells were drilled in these areas and, all else constant, average cost was significantly greater at the 5\% level than average drilling costs for other wells by about $\$ 285$ thousand. At the 5\% level, however, a well drilled in big game (elk, mule deer, or pronghorn) habitat or migratory routes, however, is no more costly than a well drilled outside these areas.

The added controls for cultural artifacts and wildlife habitat in the column (3) regression do not appear to completely account for the difference in average drilling costs on federal versus private property. The coefficient of the federal land dummy variable is positive ( $\$ 140$ thousand) and significantly different from zero at the 5\% level. The possibility of asymmetric protection of biological and cultural resources 
on private and federal property is explored by obtaining separate estimates of equation (1) by land type. In these regressions, the biological and cultural resource variables are interacted with well depth. Both survey evidence and Congressional testimony, previously discussed, suggest the federal land cost premium increases with well depth because deeper wells require more time to drill and drilling of deep wells is more likely to be interrupted by the more stringent enforcement of regulations prevailing there.

\subsection{Biological and cultural resource model by land type}

Separate regressions for federal and private property are shown in columns (4) and (5) of Table 2. The column (4) regression is estimated with the 991 observations available for wells drilled on federal property and the column (5) regression uses the 1366 observations available for wells drilled on private land. Both regressions include a full set of interactions between well depth and the biological and cultural resource variables. In the federal land regression, $\mathrm{R}^{2}=0.59$ and in the private land regression $\mathrm{R}^{2}=0.66$. Both field and time effects are jointly significant at the $5 \%$ level in each regression.

Comparing equations (4) and (5) reveals that crucial differences arise in the structure of drilling costs on federal and private property, depending on whether the land has biological or cultural resources. For biological resources, the presence of threatened and endangered species increases drilling costs significantly on both federal and private land. In the federal property regression, coefficients of interactions of shallow and deep wells with threatened and endangered species habitat are positive and significantly different from zero at $5 \%$. Similarly, for the private property regression, coefficients of interactions between mid-range depth and deep wells with endangered species habitat are significantly different from zero at 5\%. Nonetheless, a Chow test rejects the null hypothesis of equal coefficients of these three variables across the two regressions (Fisher 1970). Estimates in both regressions also suggest that extra costs associated with protection of threatened and endangered species increase with well depth. The null hypothesis that the three variables formed by interacting threatened and endangered species with well depth have equal slopes is rejected at 5\% in both the federal and private property regressions. Columns (4) and (5) show that drilling a well in a big game habitat or migratory route has no effect on costs on either type of land. Overall, these findings partly support James Hackett's (2001) Congressional testimony that biological resources are protected from drilling activities on both private and federal land. Results suggest that protection extends only to threatened and endangered species (listed or candidate), but not to other wildlife like a big game.

Additionally, the increased drilling costs associated with presence of threatened and endangered species are at least broadly consistent with the way in which these biological resources are protected. For instance, since the 1980s, sage grouse protection standards have been codified into two protection stipulations in various Bureau of Land Management Resource Management Plans: “(I) surface disturbance 
within 0.25 mile of a Sage Grouse lek will be avoided (No Surface Occupancy); and (II) operators will restrict construction activities from March 1 through July 31 within a 2.0-mile radius of active Sage Grouse leks in suitable Sage Grouse nesting habitat as determined during on-site reviews of proposed development (seasonal restriction)" (Western Governors Association, 2004, p. 86). A lek is a localized courting place and traditional courtship display and breeding area attended by male sage-grouse in or adjacent to sagebrush-dominated habitat. As noted by Elcock (2004, p. 30), these stipulations both delay projects and force drilling operations to be conducted during narrow windows in the spring or winter.

Over the last two decades, the number and implementation of protections for sage grouse as increased for specific sites. For example, Wyoming's sage grouse protection plan (2013), recommends several additional management practices for both general mineral and oil/gas development that can raise drilling costs. An operator should (I) develop a plan that addresses the needs of sage-grouse by placing and spacing well sites and roads, carefully timing travel, locating pipelines, building or removing fences, avoiding construction of overhead lines and other perch sites, reducing noise from industrial development or traffic, controlling water production, and controlling dust to minimize impacts. In addition, the operator should (II) not drill or permit new or expand existing sand and gravel activities within two miles of active sage-grouse leks between March 15 and July 15; (III) avoid surface disturbance or occupancy on or within 0.25 miles of known active lek sites; (IV) avoid human activity adjacent to leks during the breeding season between the hours of 8 p.m. and 8 a.m.; (V) use directional drilling or multiple wells from the same pad (when technically and economically feasible); and minimize the use by predators of sage grouse habitat.

With regard to mountain plover, the Bureau of Land Management also continues to conserve proactively this species, reducing the likelihood of a future need to list it as endangered. These additional protective activities can serve to increase drilling costs on private and public lands. The 2013 Mountain Plover Screen attempts to resolve the effects of oil and gas activities on the ground nesting birds. Mountain plover generally arrive on their breeding grounds in Wyoming from the last week in March to around the end of April with actual breeding/nesting beginning around mid-April. The breeding season continues through mid-July. If a surface disturbing activity is requested to take place or is in progress in mountain plover habitat during the breeding/nesting season, presence/absence surveys are required. These surveys take place within a 0.25 mile buffer around the activity and must not occur during poor weather conditions. If cold, wet weather pushes the nesting period later into the spring, the surveys would also need to be pushed back accordingly. These surveys attempt to identify the vast majority of nesting mountain plovers with the intent of reducing the risk to the nesting habitat. No surface disturbing activity is allowed to occur until all surveys have been completed and one of the following two findings has taken place. (I) If no birds are found, the disturbing activity must commence within 72 hours. If the disturbing activity doesn't commence within 72 hours, an additional survey will be required to check for late nesting, which will 
start the clock again giving another 72 hour time period. (II) If mountain plover are found, the disturbing activity must be postponed until after July $10^{\text {th }}$.

Further comparisons of columns (4) and (5) in Table 2 reveal that land type matters for the protection of cultural resources and that the cost differential increases with well depth. In the federal property regression, drilling costs for shallow wells rise significantly at the $5 \%$ level by about $\$ 10.9$ thousand for each additional site in a section whereas, for the deepest wells, drilling costs increase by about $\$ 32.1$ thousand per site. In the private property regression, on the other hand, coefficients of the cultural sites variable and its interactions with well depth are not significant at $5 \%$. Also, the numerical magnitudes of these coefficients are relatively smaller than those in the federal property regression. This outcome is broadly consistent with survey evidence indicating that while federal land managers are required to identify and preserve Native American artifacts and historical sites along the original wagon trails, private landowners sometimes view items of cultural significance as their own and on occasion have been reluctant to allow archeological surveys on their property. Cultural sites may well be more exhaustively enumerated on federal property and, once identified, may receive a greater level of protection. Net federal property drilling cost increases attributable to biological and cultural resource protection can be estimated for a mean well in the land area by differencing statistically significant coefficient estimates evaluated at their respective means. Table 3 contains specific calculations along these lines using estimates from columns (4) and (5) in Table 2. Results suggest that for the average well, threatened and endangered species protection accounts for approximately $\$ 10$ thousand of the difference in drilling cost between federal and private property, while cultural resource protection accounts for an additional $\$ 114.3$ thousand. The sum of these estimates accounts for $54 \%$ of the raw mean difference of $\$ 231$ thousand and $76 \%$ of the difference (\$162.6 thousand) reported in the baseline regression (Table 2, Column (2)). Differences in costs that remain unexplained could be due to a combination of inherent biases in self-reported firm cost data and a Niskanen (1971) type public choice argument for the government bureau. In this case, internal management directives by public land managers create incentives for greater protection on public lands. 
Table 3: Net Drilling Cost Increases due to Biological and Cultural

Resource. Protection (in thousands of 2000 dollars)

\begin{tabular}{|c|c|c|c|c|}
\hline & $\begin{array}{c}\text { Federal } \\
\text { Property } \\
\text { (Mean*Coefficient) }\end{array}$ & $\begin{array}{c}\text { Private } \\
\text { Property } \\
\text { (Mean*Coefficient) }\end{array}$ & Net & Total \\
\hline $\begin{array}{l}\text { Interaction of shallow depth and } \\
\text { elk, mule deer, pronghorn habitat }\end{array}$ & $\mathrm{a}$ & $\mathrm{a}$ & 0 & \\
\hline $\begin{array}{l}\text { Interaction of mid-range depth and } \\
\text { elk, mule deer, pronghorn habitat }\end{array}$ & $\mathrm{a}$ & $\mathrm{a}$ & 0 & \\
\hline $\begin{array}{l}\text { Interaction of deep depth and elk, } \\
\text { mule deer, pronghorn habitat }\end{array}$ & $\mathrm{a}$ & $\mathrm{a}$ & 0 & \\
\hline Big game increase & & & & $\$ 0$ \\
\hline $\begin{array}{l}\text { Interaction of shallow depth and } \\
\text { mountain plover/sage grouse habitat }\end{array}$ & $0.045 * 238.7=10.7$ & $\mathrm{a}$ & 10.7 & \\
\hline $\begin{array}{l}\text { Interaction of mid-range depth and } \\
\text { mountain plover/sage grouse habitat }\end{array}$ & $\mathrm{a}$ & $0.011 * 141.9=1.5$ & -1.5 & \\
\hline $\begin{array}{l}\text { Interaction of deep depth and } \\
\text { mountain plover/sage grouse habitat }\end{array}$ & $0.003 * 559.9=1.7$ & $0.002 * 450.8=0.9$ & 0.8 & \\
\hline $\begin{array}{l}\text { Threatened and endangered } \\
\text { increase }\end{array}$ & & & & $\$ 10.0$ \\
\hline $\begin{array}{l}\text { Interaction of shallow depth and } \\
\text { number of cultural sites }\end{array}$ & $2.24 * 10.9=24.4$ & $\mathrm{a}$ & 24.4 & \\
\hline $\begin{array}{l}\text { Interaction of mid-range depth and } \\
\text { number of cultural sites }\end{array}$ & $\mathrm{a}$ & $\mathrm{a}$ & 0 & \\
\hline $\begin{array}{l}\text { Interaction of deep depth and } \\
\text { number of cultural sites }\end{array}$ & $2.80 * 32.1=89.9$ & $\mathrm{a}$ & 89.9 & \\
\hline Cultural increase & & & & $\$ 114.3$ \\
\hline Total drilling cost increase & & & & $\$ 124.3$ \\
\hline
\end{tabular}

${ }^{\text {a }}$ coefficients not significant at the 5\% level 


\section{Conclusion}

The Railway Act land transaction provides a unique natural experiment to test whether biological and cultural regulations actually increase the operating costs to the natural gas industry. Given the shortage of such real world revealed cost studies, our findings are illuminating for public policy. Our results suggest that they can, but cost increases depend both on the protected resource and the land type. The presence of threatened and endangered species increase drilling costs significantly on both federal and private lands; whereas the existence of migratory wildlife like elk and pronghorn do not. Cultural resources have a differentiated impact: they raise the costs significantly on federal lands, but not on private lands.

What general regulatory lesson can one take from this specific natural experiment? First and foremost, our findings reinforce the need to account for the heterogeneous determinants underlying the costs of environmental regulation. Despite prevalent claims, not all resources types are more vigilantly and equally protected on federal property than on private property. The challenge is to identify which protected biological and cultural resources actually raise costs versus those that raise public ire about costs. 


\section{References}

[1] Hackett, J. T. (2001). March 15, 2001 Testimony on Behalf of the Domestic Petroleum Council before the House Subcommittee on Energy and Mineral Resources.Washington, D.C.: U.S. House of Representatives.

[2] Committee on Resources. (2001). Subcommittee on Energy and Mineral Resources, Testimony from oversight hearings conducted on March 15, March 22, and September 6, 2001. Washington, D.C.: US House of Representatives.

[3] Harder, B., C. John, and A. Dupont. (1995). Impacts of Environmental Regulations on Future Resource Development in Louisiana Wetlands. Society of Petroleum Engineers, Paper Number 009707.

[4] Penn, B. (1986). Drilling on Forest Land. Society of Petroleum Engineers, Paper Number 15153.

[5] Brown, Jr., G. M. et all. (1998). Economics of the Endangered Species Act. Journal of Economic Perspectives, 12(3), pp. 3-20.

[6] Montgomery, C., G.M. Brown and D. Adams. (1994). The Marginal Cost of Species Preservation: The Northern Spotted Owl. Journal of Environmental Economics and Management, 26(2), pp. 111-128.

[7] Huppert, D. (1999). Snake River Salmon Recovery: Quantifying the Costs. Contemporary Economic Policy, 17(4), pp. 476-491.

[8] Watts, G., W.R. Noonan, H.R. Maddux and D.S. Brookshire. (2001). The Endangered Species Act and Critical Habitat Designation, in Protecting Endangered Species in the United States: Biological Needs, Political Realities, and Economic Choices, Cambridge University Press, New York, NY.

[9] American Petroleum Institute. (2005). Joint Association Survey on Drilling Costs. Washington, D.C.

[10] Wooldridge, J. M. (1995). Selection Corrections for Panel Data Models under Conditional Mean Independence Assumptions. Journal of Econometrics, 68(1), pp. 115-132.

[11] Baltagi, B. H. (2005). Econometric Analysis of Panel Data. John Wiley \& Sons Ltd. Chichester, England.

[12] Pesaran, M. H. (2004). General Diagnostic Tests for Cross Section Dependence in Panels University of Cambridge paper \#435.

[13] Breusch, T. S. and A. R. Pagan. (1980). The Lagrange Multiplier Test and its Application to Model Specifications in Econometrics. Review of Economic Studies, 47(1), pp. 239-253.

[14] Fisher, F. M. (1970). Tests of Equality between Sets of Coefficients in Two Linear Regressions: An Expository Note. Econometrica, 28(2), pp. 361-366.

[15] Western Governors Association. (2004). Conserving the Greater Sage Grouse: A compilation of efforts underway on State, Tribal, Provisional, and Private Lands, WGA, Denver, CO. http://www.westgov.org/wga/initiatives/grouse/sagegrouse-rpt.pdf 
[16] Elcock, D. (2004). Environmental Policy and Regulatory Constraints to Natural Gas Production, Environmental Assessment Division, Argonne National Laboratory, Washington, D.C., December. http://www.pi.energy.gov/pdf/library/NaturalGasFinal.pdf.

[17] Wyoming Game and Fish Department. (2013). Wyoming Greater Sage Grouse Conservation Plan, Cheyenne, Wyoming. http://gf.state.wy.us/wildlife/wildlife_management/sagegrouse.asp

[18] Bureau of Land Management. (2013). Mountain Plover Project Screen. http://www.blm.gov/nhp/efoia/wo/fy04/034attach2.pdf

[19] Niskanen, W., Jr. (1971). Bureaucracy and Representative Government. Aldine-Atherton, Chicago, IL. 


\section{Appendix}

Table A1: Determinants of Real Drilling Cost (in thousands of 2000 dollars) Sample Selection Model a

\begin{tabular}{|c|c|c|c|c|}
\hline Variable & $\begin{array}{c}\text { Baseline } \\
\text { Model }\end{array}$ & $\begin{array}{c}\text { Historical/ } \\
\text { Biological }\end{array}$ & $\begin{array}{r}\text { Federal } \\
\text { Property }\end{array}$ & $\begin{array}{c}\text { Private } \\
\text { Property }\end{array}$ \\
\hline Constant & $\begin{array}{l}508.4^{*} \\
(41.5)\end{array}$ & $\begin{array}{l}361.4^{*} \\
(44.8)\end{array}$ & $\begin{array}{l}391.0^{*} \\
(82.9)\end{array}$ & $\begin{array}{l}710.5^{*} \\
(42.5)\end{array}$ \\
\hline $\begin{array}{l}=1 \text { if well is located on federal property, } 0 \\
\text { otherwise }\end{array}$ & $\begin{array}{l}158.2^{*} \\
(28.7)\end{array}$ & $\begin{array}{l}138.3^{*} \\
(28.8)\end{array}$ & -- & -- \\
\hline $\begin{array}{l}=1 \text { if well depth is between } 9,750 \text { and } 11,450 \text { feet, } 0 \\
\text { otherwise }\end{array}$ & $\begin{array}{l}489.6^{*} \\
(44.3)\end{array}$ & $\begin{array}{l}578.1^{*} \\
(45.7)\end{array}$ & $\begin{array}{l}707.9^{*} \\
(93.6)\end{array}$ & $\begin{array}{l}288.4^{*} \\
(49.5)\end{array}$ \\
\hline $\begin{array}{l}=1 \text { if well depth is greater than } 11,450 \text { feet, } 0 \\
\text { otherwise }\end{array}$ & $\begin{array}{c}1,559.5^{*} \\
(60.2) \\
\end{array}$ & $\begin{array}{c}1,625.0^{*} \\
(60.3)\end{array}$ & $\begin{array}{l}1,929.3^{*} \\
(109.9) \\
\end{array}$ & $\begin{array}{l}883.0^{*} \\
(62.8)\end{array}$ \\
\hline $\begin{array}{l}=1 \text { if well is in elk, mule deer or pronghorn } \\
\text { habitat/migratory routes, } 0 \text { otherwise }\end{array}$ & -- & $\begin{array}{l}72.9 \\
(43.1)\end{array}$ & -- & -- \\
\hline $\begin{array}{l}\text { Interaction of shallow depth and elk, mule deer, } \\
\text { pronghorn habitat }\end{array}$ & -- & -- & $\begin{array}{c}218.1 \\
(171.9) \\
\end{array}$ & $\begin{array}{l}-20.3 \\
(86.1)\end{array}$ \\
\hline $\begin{array}{l}\text { Interaction of mid-range depth and elk, mule deer, } \\
\text { pronghorn habitat }\end{array}$ & -- & -- & $\begin{array}{c}173.7 \\
(191.3)\end{array}$ & $\begin{array}{c}67.5 \\
(73.6) \\
\end{array}$ \\
\hline $\begin{array}{l}\text { Interaction of deep depth and elk, mule deer, } \\
\text { pronghorn habitat }\end{array}$ & -- & -- & $\begin{array}{l}-63.9 \\
(91.0) \\
\end{array}$ & $\begin{array}{c}80.3 \\
(49.2) \\
\end{array}$ \\
\hline $\begin{array}{l}=1 \text { if well is in mountain plover or sage grouse } \\
\text { habitat, } 0 \text { otherwise }\end{array}$ & -- & $\begin{array}{l}284.9^{*} \\
(62.9)\end{array}$ & -- & -- \\
\hline $\begin{array}{l}\text { Interaction of shallow depth and mountain } \\
\text { plover/sage grouse habitat }\end{array}$ & -- & -- & $\begin{array}{c}220.1 \\
(123.1)\end{array}$ & $\begin{array}{c}45.6 \\
(67.9) \\
\end{array}$ \\
\hline $\begin{array}{l}\text { Interaction of mid-range depth and mountain } \\
\text { plover/sage grouse habitat }\end{array}$ & -- & -- & $\begin{array}{c}323.1 \\
(409.8) \\
\end{array}$ & $\begin{array}{l}144.3^{*} \\
(12.2)\end{array}$ \\
\hline $\begin{array}{l}\text { Interaction of deep depth and mountain plover/sage } \\
\text { grouse habitat }\end{array}$ & -- & -- & $\begin{array}{l}569.4^{*} \\
(140.4)\end{array}$ & $\begin{array}{l}414.9^{*} \\
(117.8)\end{array}$ \\
\hline $\begin{array}{l}\text { Number of cultural sites in a section where a well is } \\
\text { drilled }\end{array}$ & -- & $\begin{array}{r}11.9^{*} \\
(2.3) \\
\end{array}$ & -- & -- \\
\hline $\begin{array}{l}\text { Interaction of shallow depth and number of cultural } \\
\text { sites }\end{array}$ & -- & -- & $\begin{array}{l}10.1 \\
(5.7)\end{array}$ & $\begin{array}{c}1.2 \\
(3.1)\end{array}$ \\
\hline $\begin{array}{l}\text { Interaction of mid-range depth and number of } \\
\text { cultural sites }\end{array}$ & -- & -- & $\begin{array}{l}-6.9 \\
(9.8) \\
\end{array}$ & $\begin{array}{l}-0.1 \\
(5.7) \\
\end{array}$ \\
\hline $\begin{array}{l}\text { Interaction of deep depth and number of cultural } \\
\text { sites }\end{array}$ & -- & -- & $\begin{array}{l}32.2^{*} \\
(5.5)\end{array}$ & $\begin{array}{c}1.3 \\
(4.2)\end{array}$ \\
\hline$=1$ if an oil well, 0 otherwise & $\begin{aligned}-479.4^{*} \\
(84.4) \\
\end{aligned}$ & $\begin{array}{l}-475.7^{*} \\
(83.6) \\
\end{array}$ & $\begin{array}{l}-759.3^{*} \\
(141.8) \\
\end{array}$ & $\begin{array}{l}-30.2 \\
(80.7) \\
\end{array}$ \\
\hline$=1$ if a dry hole, 0 otherwise & $\begin{array}{l}-219.9^{*} \\
(72.0) \\
\end{array}$ & $\begin{aligned}-194.8^{*} \\
(71.3) \\
\end{aligned}$ & $\begin{array}{l}-381.8^{*} \\
(142.2)\end{array}$ & $\begin{array}{l}-24.4 \\
(62.5) \\
\end{array}$ \\
\hline Sample selection added variable & $\begin{array}{l}-0.024 \\
(0.014)\end{array}$ & $\begin{array}{l}-0.008 \\
(0.014)\end{array}$ & $\begin{array}{l}-0.051 \\
(0.032)\end{array}$ & $\begin{array}{l}-0.015 \\
(0.012)\end{array}$ \\
\hline Number of observations & 2357 & 2357 & 991 & 1366 \\
\hline Fixed effects vs Random effects, Hausman (df) & $83.8(6)$ & $150.7(9)$ & $83.6(14)$ & $86.2(14)$ \\
\hline Field effects, F-test (df) & $\begin{array}{c}16.5 \\
(54,2296)\end{array}$ & $\begin{array}{c}16.9 \\
(54,2293)\end{array}$ & $\begin{array}{c}12.1 \\
(44,932)\end{array}$ & $\begin{array}{c}13.4 \\
(50,1301)\end{array}$ \\
\hline $\begin{array}{l}\text { Time effects after removing Field effects, F-test } \\
\text { (df) }\end{array}$ & $\begin{array}{c}14.9 \\
(17,2279) \\
\end{array}$ & $\begin{array}{c}14.9 \\
(17,2276) \\
\end{array}$ & $\begin{array}{c}7.8 \\
(17,915) \\
\end{array}$ & $\begin{array}{c}14.5 \\
(17,1284) \\
\end{array}$ \\
\hline $\mathrm{R}^{2}$ & 0.49 & 0.51 & 0.59 & 0.66 \\
\hline
\end{tabular}

